DOI 10.15826/umpa.2020.02.020

\title{
OUTBOUND STUDENT MOBILITY IN RUSSIA: CREATING A PATH FOR BRAIN CIRCULATION THROUGH HIGHER EDUCATION
}

\author{
E. A. Minaeva \\ National Research University «Higher School of Economics» \\ 16 Potapovsky lane, b. 10, Moscow, 101000, Russian Federation; \\ eminaeva@hse.ru
}

\begin{abstract}
Given the ambitious national strategies for science, innovations and university development in Russia, the availability for young highly qualified specialists who can be competitive at the global job market, is vital. At the same time, as of now, Russia, unlike many other countries, does not have a comprehensive set of initiatives addressing the brain drain among Russian students that obtain their degrees abroad.

This article provides an analysis of motivations of Russian perspective graduate (master and doctoral) students who plan to study abroad and emigrate after graduation, as well as the factors that may positively affect their decision to return to Russia. In addition, the research provides an overview of international policies and practices to prevent the brain drain, and the opportunities for developing such policies in our country.

Keywords: brain drain, internationalization, intellectual capital, student mobility, brain circulation

For citation: Minaeva E. A. Outbound Student Mobility in Russia: Creating a Path for Brain Circulation through Higher Education.
\end{abstract}

University Management: Practice and Analysis. 2020; 24 (2): 145-156. DOI: 10.15826/umpa.2020.02.020.

As many experts point out, internationalization of education, and particularly student mobility, together with multiple benefits brings tangible risks, including brain drain and loss of best and brightest students to more prosperous economies [1-3]. The brain drain is not a new challenge for both developed and developing countries, and some states have already worked out comprehensive and successful practices to retain their outgoing students and engage them into the national job market.

In case of Russia, many scholars see the outbound student mobility as a risk of a brain drain [4, 5]. Being a somehow politically charged topic, this Issue is widely discussed in media and research publications; however, most of these discussions have a theoretical nature. Currently there is no analytics on this topic based on comprehensive data, and, therefore, the opportunities for addressing this Issue by developing sophisticated policies are quite limited.

The research aims to answer the following questions:

1) What is the portrait of the Russian students that plan to go abroad? What are the factors that encourage students to seek higher education outside Russia?

2) What are the attitudes of Russian students towards employment in the host country after graduation?
3) What encourages students to return to Russia after graduation abroad?

The research focuses on prospective students who apply for studying abroad on a graduate level (master and doctoral programs). There are two reasons for choosing perspective master students as a sample for this research:

1) graduate students are close to entering the job market in 2-4 years, and, therefore, the research allows to investigate both motivations for studying abroad and for choosing a job market to focus on after graduation;

2) graduate students are usually older than undergraduate students, and, therefore, their decisionmaking can be assumed to be more thought through, and responsible, and «strategic» in nature.

In addition, the research provides an overview of national and institutional practices that aim to reduce the brain drain through education in other countries. The author studies the Russian policy instruments addressing this Issue and provides suggestions for further policy development on national and institutional levels based on the analysis of students' attitudes and motivations.

\section{Internationalization of education and brain drain}

Student mobility is a big part of internationalization in higher education. The most common definition 
for internationalization was given by J. Knight [6], who sees this phenomenon as a necessary «process of integrating an international, intercultural, or global dimension in the purpose, functions, or delivery of postsecondary education» [6]. There is no doubt that for the past several decades, internationalization has dramatically changed the landscape of higher education [7]. Being a major component of internationalization, student mobility has drawn the attention of many educators, policymakers and researchers, both due to its current effect on economic, cultural, political and social aspects nationally and globally, and due to the growing numbers of international students. In 2013, over 4.1 million students went abroad to study, an increase from two million in 2000, representing 1.8 percent of all tertiary enrollments, or two out of each 100 students, globally $[8,9]$.

Competition for talent and its value for the national economies is one of the main rationales for student mobility and education export. For some countries, the ability to attract international students and top academic talent to a country is an important condition of its prosperity. For example, some states, such as Hong Kong and Singapore, position themselves as «educational hubs» [7]; in such countries, the prestige of education and research is a crucial factor of prosperity and economic growth, and national governments put tangible effort into sustaining and enhancing their reputation and ability to attract the most talented students from all over the globe [2].

While this phenomenon has a number of important positive global outcomes for all stakeholders (students, institutions, receiving countries and sending countries), it also contributes to further global asymmetry and imbalance. Scholars underline that, in fact, developing economies are contributing significantly to the academic systems of wealthier states [1]. There are a number of established leaders in international education: the USA, the UK, Canada, Australia, Western European countries (particularly, the Netherlands, Germany, and France). These countries are the rule-setters in the international academic landscape; they determine the traditions of scientific discourse and standards of both higher education and research [10], and these countries are the most attractive destinations for international students. Many factors, such as academic excellence, prestige, and career prospects in the developed countries, appear to be attractive for students. The major education actors also realize the benefit in accommodating the «best and the brightest». For example, countries like Canada, USA, the Netherlands, Germany, and Australia provide open employment opportunities; permit postgraduate work and easier degree recognition; facilitate cooperation between the universities, governments, and industry etc. [1].

Meanwhile, for many developing countries the starting position is far from beneficial, and, therefore, they are not strong competitors in the global higher education market. The risks related to the brain drain of students and young professionals through international education remain a concern despite some advantages of brain circulation [3]. The problem of student brain drain is often rooted in a large gap between the conditions in the developed countries and the benefits that the home country can offer. Some of the most significant push-factors, which encourage students to go abroad and then emigrate, are related to corruption, economic stagnation, deep social problems and lacking democratic freedoms in their home countries. These issues cannot be solved overnight, and achieving competitive advantages in the race for talent may take decades for some states.

In addition, their disadvantages in terms of economic competitiveness, lower quality of life and salary levels, less robust job markets and other issues further encourage internationally mobile students from those countries to stay abroad. P. Altbach [11] emphasizes the need for solidarity and responsibility of the developed countries in this issue. However, current trends do not reveal such attitude [11, 12]. Indeed, as Altbach underlines,

...there is absolutely no recognition of any contradiction between, for example, Millennium Development Goals, which stress the necessity for educational development in the emerging nations, and policies aimed at attracting the best brains from developing countries [1, p. 43].

These observations are relevant not only for the developing countries. For example, in the EU countries with a less competitive economy compared to their Western neighbors, such as Lithuania [13] or Italy [14], the concerns about migration of the best and brightest to Western Europe through education are at place for more than a decade by now.

\section{Policy responses to the brain drain}

Some countries have recognized the Issue of the brain drain on the national level and managed to elaborate comprehensive policies which have turned out to be quite successful in preventing brain drain and even achieving brain gain - for example, in the case of Singapore [15]. Some of these measures do not differ from the responses to the emigration of skilled labor in general; for example, the development of competitive job opportunities. However, there are a number of 
initiatives targeting students specifically. G. Gribble indicates three types of policies addressing the issue: retention, return, and engagement [15].

Retention is associated with the initiatives that encourage students to obtain higher education in their home countries. Retention can be achieved through decreasing the strength of the factors that encourage students to seek higher education abroad - for example, by improving quality of education in the country. Additional funding for research and technology also pays off as a successful way to retain students and young researchers. For example, Brazil spends $1 \%$ of its gross domestic product (GDP) on developing science and supporting young researchers [16], which not only decreased the emigration of young professionals, but made Brazil a regional hub for higher education [17]. Another way to retain students is to encourage studying in foreign institutions but via mechanisms that do not provide as many emigration opportunities after graduation. For instance, a country may create conditions for establishing branch campuses and provide an opportunity for students to obtain an international qualification without leaving the country (good examples of such practice can be seen in Singapore and Hong Kong). Another possible way to retain students is the creation of doubledegree programs and other forms of student mobility, which would keep them affiliated with the university at home. Such initiatives allow participants to benefit from the positive outcomes of student mobility, but they significantly decrease the risk of migration for many reasons, including the fact that visa regulations for exchange and short-term courses usually do not allow students to seek employment in the host country after graduation.

Another way to address the brain drain is related to the policies that aim to get students to return after graduation. One way to do this is through scholarship programs that include an obligation to return to the home country after graduation; an example of this can be seen in the Bolashak program («Bolashak International Scholarship», n.d.) in Kazakhstan. More importantly, a government can increase the influence of the home country's pull-factors by changing the environment for returnees [18]. Initiatives here can include preferential policies, such as beneficial conditions for housing loans, improved employment conditions, establishment of career centers for returnees or reimbursement of tuition fees paid by self-funded students.

The third approach, the engagement of students who have a strong intention to immigrate, is based on enabling various opportunities for brain circulation. One of the good practices in this regard is the «diaspora approach» $[19,20]$, which aims to create connections between immigrants and their original home country so as to provide brain circulation and maintain bonds with the home country in case they would want to return in future. The Chinese experience in keeping a connection with Chinese graduates overseas (as well as other groups of emigrants) through diaspora networks has been quite successful and allowed qualified emigrants «to engage with the home country from abroad» [15]. Diaspora networks also provide additional opportunities for transnational entrepreneurship. A. Saxenian [21] provides bright examples of positive implications of the transnational networks of India- and China-born entrepreneurs, scientists and engineers of Silicon Valley and their cooperation with their countries of origin.

In addition, the home country can engage emigrated professionals who do not plan to return home by providing opportunities for their temporary employment. Many of these professionals possess valuable knowledge, expertise, scientific capacity, and upto-date technological proficiency, which can be applied to advisory and consultancy services and, again, for the establishment of professional networks.

This research focuses on student mobility in the context of Russia; trends and specific issues of international student mobility in the national context are analyzed in the next section.

\section{Recent Russian policy initiatives addressing student retention and brain circulation}

The inbound and outbound mobility flows in Russia are uneven.

Russia is ranked 6th among countries with the highest numbers of inbound mobility - that is, with more than 310000 of international students. The main student flow (around 70\% of all international students) comes to Russia from CIS countries, which is explained by the high number of pull-factors for this group of students: most of CIS students speak Russian; they are familiar with the Russian culture, and many of them study in Russia by the advice of their parents who have received higher education in Russian institutions; many CIS students have family connections in Russia; the migration regulations and tuition fees for this group are much more beneficial than for other international students (Fig. 1).

Another significant flow of students comes to Russia from China (around 8\%), which is explained by economic connections between the two countries.

The most popular majors for international students at Russian institutions are healthcare (20\%), 


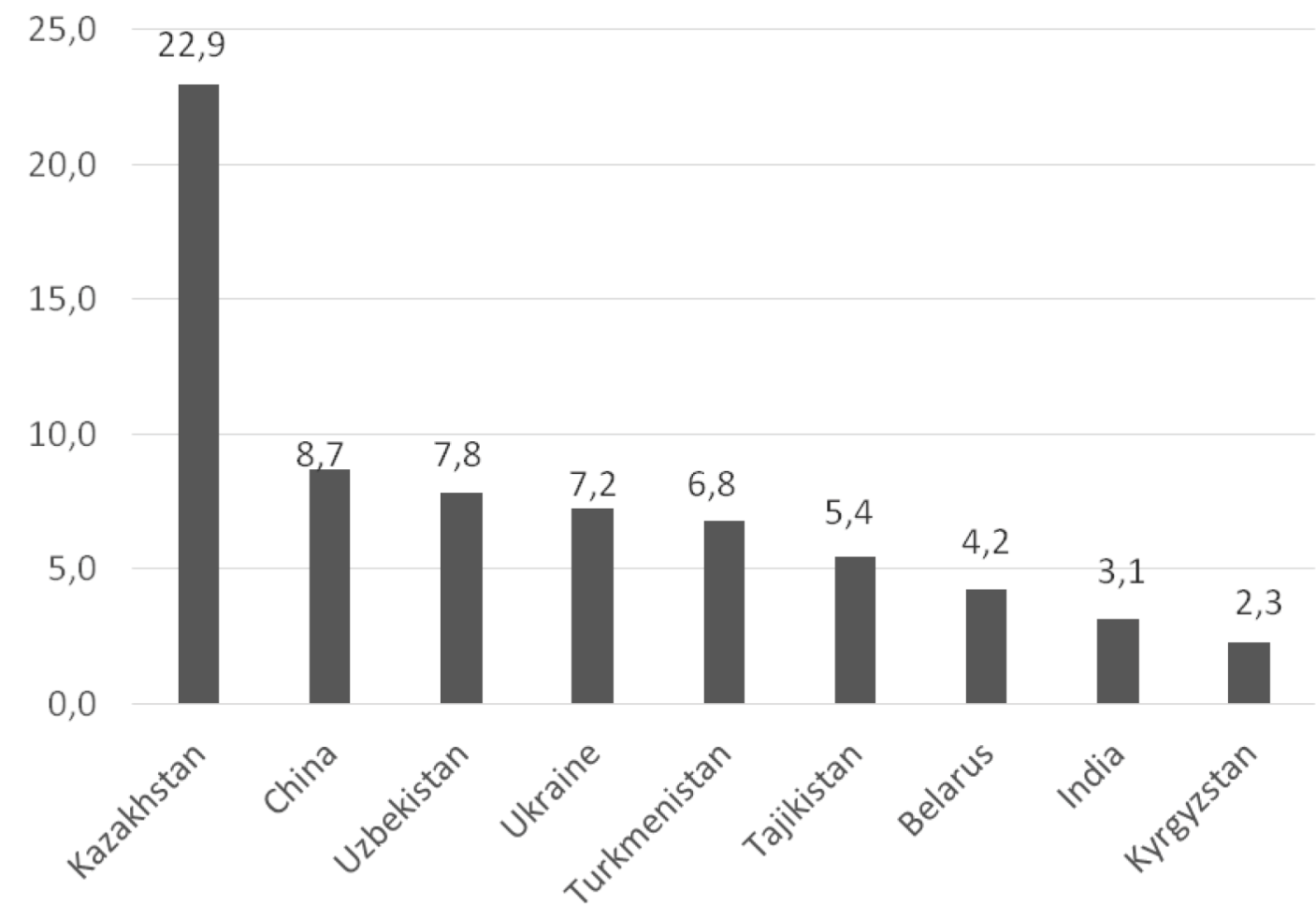

Fig. 1. Share of international students in Russia by country from top-10 destinations, 2017

economics and management (13\%), humanities (11\%), and the Russian language (8\%).

Currently, there are no data which would represent the statistics of employability of international students in Russia; the attitudes towards international students at the Russian job market are also overlooked, which demands a more detailed research on these topics.

At the same time, the percentage of Russian students who obtain international education (which stood at approximately $1 \%$ in 2017) is comparatively low. While Russia is one of the world's major receiver countries of internationally mobile students, the number of Russian students studying abroad is around 50,000 , while the overall number of students in Russia is 4.7 million [22].

Currently, there are some modest data on Russian students' motivations for obtaining higher education degrees abroad and their attitudes towards choice of study destination and plans after graduation available from national reports of other countries. The purpose of such works was, however, to understand Russian attitudes towards specific countries, for example, in relation to the Netherlands [23], Norway [24] or the United Kingdom [25]. At present, there is no complete picture grounded in data on Russian students' attitudes towards studying abroad and further immigration, and no comprehensive analysis of push- and pull-factors that affect their choices and their possible decision to return to the Russian job market.
On the national level, the challenges of outbound student mobility and student brain drain are mostly addressed by two types of initiatives: retention and return. The government approaches retention policies through various initiatives for development and quality increase in higher education. The initiatives for return are usually related to the scholarships which require students to return to Russia after graduation.

The most significant federal initiative addressing development of human potential through outbound student mobility and development is the scholarship program «Global Education», launched in 2014. The program targets Master and $\mathrm{Ph}$. D. students, and provides funding for those who were successfully admitted to study programs abroad. The program states several priority fields of study (science, engineering, education, medical studies, and social management). There are two conditions for participation in the program: first, students should apply to one of 228 universities preapproved by the program, and second, students are obliged to return to Russia within 30 days after graduation. The selection of international universities participating in the program is based on their research and academic reputation and on the needs of the Russian job market. As of December 2017, 774 students had been granted fully-funded scholarships, and 55 students had graduated and entered the Russian labor market [26]. However, the share of students funded by the «Global Education» program is rather insignificant compared to the overall number of Russian degree-mobile students. 
Another policy that can be considered as a retention mechanism is the $\ll 5-100 »$ program, which aims to bring Russian higher education institutions to top positions in the world university rankings, such as the QS University Ranking or Times Higher Education Ranking. The extended funding provided for the institutions-participants allowed universities to spend more on trainings for academics, improving laboratory equipment, renovating study programs and attracting foreign professors and students.

At the end of 2016, another project was launched to increase the competitiveness of Russian higher education. The first project, «Universities as Centers for Creating Innovations», addresses challenges of innovation, technological and social development in different regions of Russia. The aim of the project is to increase the number of innovation centers as well as the involvement of the Russian regions in this initiative.

Another effort initiated in 2017 is the federal program «Education Export» [22]. The initiative seeks to develop the legislative framework for attracting international students to the job market and new forms of study, to elaborate instruments for active promotion of Russian higher education abroad, to enhance human resources development in the universities and the overall competitiveness of Russian higher education. Even though the initiative is targeting international students and considers the increase of revenue as a primary goal, the program may contribute to the development of the overall internationalization of Russian institutions and demand for the Englishspeaking faculty which may create a demand at the Russian job market for Russian Ph. D. and Master students graduating from foreign institutions. However, these two policies may have a rather indirect effect on brain drain and do not target Russian graduates of foreign institutions specifically.

On the institutional level, outbound mobility is usually addressed through exchange and double-degree programs, which also aligns with the «return» strategy. On the one hand, universities are encouraged by the government to participate in internationalization in order to increase their ranking sub-indexes; on the other hand, institutions are interested in attracting high-profile students through developing competitive programs and cooperation with foreign institutions. However, these programs are mostly developed by top institutions; the majority of universities have much less in the way of resources and opportunities for developing such programs due to managerial, organizational and financial issues [27].

The third type of policies, engagement, currently is not addressed in Russia at any level, which looks like a missed opportunity and a potential risk of further loss of high-achieving graduates to the job and academic markets of other countries.

\section{Analytical approach and data}

The dominant framework which explains the flows of international students as well as migration flows in general is the "push- and pull-factors» theory [28]. First developed by M. Todaro [29] for understanding the phenomenon of the labor migration, this theory was subsequently adjusted by P. Altbach [28] to explain the dynamics of international student flows - international students' attitudes, motivations, and choices of their study destinations.

According to this approach, students experience two types of impact. On one hand, they are «pushed» out of the country due to a lot of factors. These factors vary from country to country; however, some of them are common for many, namely: students are unable to gain access to university study in their home country; they are looking for a prestigious education that does not exist in their home country; they want to escape from discrimination or political repression; they are looking for better career opportunities, etc.

On the other hand, students can be «pulled» to certain study destinations. The most common pull factors are the high quality of the academic system of the host country; easy admission processes; in some cases (for example, in the case of German state institutions) - lower tuition fees; democracy and academic freedom; easy immigration processes and liberalized visa regulations. While the push-and-pull approach provides an overarching framework for understanding students' attitudes towards studying abroad, there are several theories which can be helpful for understanding specific push- and pull-factors affecting political, economic and social rationales of students' choices and attitudes towards studying abroad and staying abroad after graduation.

Neoclassical Economics of Migration considers two perspectives. The first approach - the Macro theory [29] - suggests that migration is caused by countries' differences in the supply and demand for labor and by the differences in wage rates between countries [30]. The theory implies that international migration flows of highly skilled labor respond to differences in the rate of return of the human capital and may differ from the flows of unskilled workers. The second approach-Micro theory-implies that individual rationales of workers have an impact on their decision to emigrate [29, 31]. These rationales are based on estimating the risks and benefits of immigration: on one hand, individuals want to achieve conditions for them to be most productive and to have the highest net rate 
of return; on the other hand, immigration requires investment and risks connected with the cost of maintenance while moving abroad, cost of travelling, adaptation to the new labor market and to the cultural norms of another country [30]. In this case, the opportunity to achieve better working and living conditions can be considered as a push-factor from the home country, and the risks in the foreign country is the factor pushing immigrants from certain destinations (it can be considered as a pull factor, if the risks in a certain country are lower than in others).

Human Capital Theory developed as a part of neoclassical economic theory. However, it puts more attention on investment in human beings and considers this the best investment that an economy or society can make [30]. According to this theory, investment in education (as well as investment in migration) increases one's chances for a better life and brings financial benefits in the future. The theory provides an explanation why such factors as easier access to higher education abroad or access to better quality of higher education abroad, recognition of foreign degrees by employers and prestige of the university can be considered as highly-motivating pull factors for students. However, in the past few years, some researchers have been arguing that human capital theory can be no longer applied to the job market, as graduation from the university does not guarantee a job, and the labor market is saturated with recent graduates [32].

The New Economics of Migration. This theory challenges the neoclassical approach for understanding migration, and argues that the decision to migrate is made not by individuals, but by larger units - for example, families or households $[33,34]$. The theory implies that a collective migration decision reduces the related risks and maximizes the expected income due to the multiple actors involved in the decision and, therefore, to the diversification of the risks during migration $[34,35]$. The new economics of migration puts the risks at the center of the discourse and claims that in developing countries the risks are higher due to lacking social programs, insurance programs and because of the overall instability, which becomes a major incentive for households in those countries to search for better conditions through migration to developed countries.

Dual Labor Market Theory, unlike the theories considered above, states that the trends in migration stem from the intrinsic labor demand of modern industrial societies [30]. Taking a macro-level approach to the migration phenomenon, the theory states that migration is caused not by the push-factors in sending countries but by the pull-factors in the receiving countries [36]. This approach can be visible in the immigration policies of many countries. For example, under the conditions of a global race for talent, developed countries put a lot of effort into providing better conditions for highly-skilled migrants, even if these immigrants have comparatively high working and living conditions in their home countries. Some countries create beneficial immigration conditions for the professionals in certain spheres according to the needs of their job market and their economic goals (for example, medicine or information techno$\log y)$, which creates the migration flows to certain areas (for example, to Silicon Valley). The demand for highly-skilled migrants grows in the developed countries, therefore the immigration flows are responding to this demand.

Network theory. T. Faist [37] claims that social ties play an important role in migration dynamics. With each new migrant, the social capital at the place of destination increases for the potential successor, and the process continues along the chains of migration and develops into a self-perpetuating dynamic [38].

Capability Approach [39] is another way to look at the process of migration. While the above-mentioned theories focus on economic rationales at the micro- and macro-level, the capability approach sees migration as individuals' attempts to expand their capabilities and freedoms [40]. This theory considers human development as the central concept; it does not exclude economic rationales but rather emphasizes other dimensions affecting students' choices. From this perspective, educational migration can be seen as an attempt to exercise students' right to get higher education and personal prosperity and development.

\section{Procedure, reliability and validity}

In order to ensure the reliability of the research, a pilot survey was conducted six months prior to the launch of the formal survey [41]. The sample size of the pilot survey was 30 students. The pilot survey allowed the reformulation of several questions to avoid their misinterpretation by the respondents, and to develop additional items of relevance. The sample was selected from the students of the paid online course «Applying to the Master's Studies Abroad» conducted by an education agency.

The content validity is ensured by the literature review and thorough analysis of the existing theoretical and empirical research on student mobility prior to coding the dimensions of the research into the survey items. The participants involved in the pilot survey differed from the participants of the formal survey, in order to provide the external validity of the research. 
The internal validity for questions with multiple sub-question sections is ensured by measuring Cronbach's alpha for these survey items.

The research has several limitations. First, the participants of the survey are those who only plan to study abroad; these students' express attitudes related to their plans, and during or after studying abroad, their opinions may change due to various factors they do not take into consideration yet. While this research intentionally covers only this group of students, in order to comprehensively understand the realities of outbound student mobility in Russia, a similar survey among current students and graduates of foreign institutions is required.

Second, students from certain regions of Russia may be underrepresented in the survey, and that may affect the results. For example, if the respondents are mostly from Moscow and Saint Petersburg, the survey may reflect their attitudes more than attitudes of students from the peripheral regions of Russia.

Third, due to the particular focus of the research, the attitudes of undergraduate Russian students were not considered in the research. Their motivations may differ from motivation of graduate students, and for development of comprehensive policies and initiatives in this field, they should be considered as well.

\section{Results}

The initial sample size consisted of 200 respondents; however, 16 responses were excluded from the sample due to the fact that they did not match the control variables such as nationality $(\mathrm{N}=10)$ or level of pursued degree abroad $(\mathrm{N}=6)$. Thus, the sample size for the analysis below is 184 respondents.

The number of respondents is not very high; however, the overall number of outgoing Russian master students is not high as well. In addition, application to the Master's programs is not a centralized procedure, and in order not to get bias in the sample and skew towards groups of students that consider a specific country destination, the authors intentionally avoided data collection from students who apply to foreign institutions through the specific recruitment agencies specializing on particular countries.

The survey required mandatory response to every question on the questionnaire, and there are no missing data in the final data sample.

The majority of our respondents are females $(78.8 \%, \mathrm{~N}=145)$, and more than half of the respondents belongs to the age group of 17-25 years old $(65.2 \%, \mathrm{~N}=120)$. The detailed distribution of the respondents according to gender is shown in Table 1.

The results show that $34.8 \%$ of the students $(\mathrm{N}=64)$ have an excellent GPA (4.9-5.0 out of 5.0). The students with a very good GPA (4.54.8 out of 5.0) and a good GPA (4.0-4.4 out of 5.0) have a share of $29.3 \%(\mathrm{~N}=54)$ and $29.9 \%(\mathrm{~N}=55)$ respectively.

Nearly half $(45.1 \%, \mathrm{~N}=83)$ of the students consider their English language skills as fluent, 38\% think their English proficiency to be advanced, and $28.8 \%$ of the respondents evaluate their English language proficiency as intermediate.

The survey shows that $33.7 \%(\mathrm{~N}=62)$ of the students are currently studying at Bachelor programs, and $37.3 \%(\mathrm{~N}=69)$ have already graduated with a Bachelor's degree. $28.6 \%(\mathrm{~N}=53)$ want to obtain a second Master's degree abroad despite the fact that they have already obtained or are currently obtaining a similar qualification in Russia.

The five most popular study destinations among Russian students are the USA $(21.1 \%, \mathrm{~N}=39)$, Germany $(20 \%, \mathrm{~N}=37)$, the UK $(18.9 \%, \mathrm{~N}=35)$, Canada $(6.5 \%, \mathrm{~N}=12)$, and Italy $(5.4 \%, \mathrm{~N}=10)$.

Indicating the attitudes towards quality of education in their home countries, $55.2 \%(\mathrm{~N}=69)$ of the students said that they consider education in their home country to be less advanced and corresponding to the modern job market requirements; $14.4 \%(\mathrm{~N}=18)$ of students think that it is possible to obtain modern high-quality education only in top Russian universities. Only $20.7 \%(\mathrm{~N}=38)$ of respondents said that Russian institutions meet the requirements of the job market; however, these respondents plan to apply for studies abroad for other reasons.

Indicating their attitudes towards studying at a double-degree program offered by a Russian and a foreign institution, $45.6 \%$ of respondents are in favour of this option rather than going abroad for a full degree, $25 \%$ of respondents indicate that they may consider this possibility, and the remaining $29.4 \%$ of students would prefer to obtain a full degree in a foreign country.

Table 1

\section{Distribution of Respondents by Age}

\begin{tabular}{|c|c|c|}
\hline Age & N & Percent \\
\hline $17-21$ & 46 & 25 \\
$22-25$ & 74 & 40.2 \\
$26-29$ & 20 & 10.7 \\
$30-33$ & 20 & 10.9 \\
$34-37$ & 10 & 5.4 \\
$38-42$ & 7 & 3.4 \\
43 or more & 7 & 3.4 \\
Total & 184 & 100 \\
\hline
\end{tabular}


Table 2 shows the distribution of students' responses on planned choices after graduation. More than $60 \%$ of students plan to stay abroad after graduation, and almost $24 \%$ of respondents plan to obtain work experience in the host country, which makes them potential emigrants as well due to the fact that during their employment abroad they may develop personal and professional connections abroad and then emigrate.

When asked to indicate the most relevant reasons to stay in the host country (Table 3), the students were allowed to choose more than one answer. The factors that encourage students to stay abroad are mostly related to the economic reasons such as higher quality of life in the host country $(18.2 \%, \mathrm{~N}=112)$, high salary rate in the host country $(15.8 \%, \mathrm{~N}=97)$, and better career opportunities abroad $(13.5 \%, \mathrm{~N}=83)$.

Among the reasons to return to Russia after graduation form a foreign institution (Table 4), the respondents indicate personal circumstances $(67.9 \%$, $\mathrm{N}=125$ ), a wish to contribute to the development of Russia $(38.5 \%, \mathrm{~N}=71)$ and financial difficulties which may require them to return home $(28.8 \%$, $\mathrm{N}=53$ ).

\section{Discussion}

Based on their motivations and plans after graduation, the students can be divided into three groups: those who will return to Russia, those who have no final decision on this question and those who plan to immigrate and consider education abroad as an avenue for immigration. The percentage of students for each group is shown in Fig. 1. In order to prevent brain drain and involve all the three groups of students in the Russian economy, each group may be considered separately and addressed by different policies.

Table 2

\section{Plans of Prospective Students after Graduation from a Foreign University}

\begin{tabular}{|l|c|c|}
\hline \multicolumn{1}{|c|}{ Students' plans after graduation from a foreign institution } & \% of answers & N \\
\hline To find a permanent job in the host country & 42.4 & 78 \\
\hline To obtain work experience in the host country and come back & 23.9 & 44 \\
\hline To pursue an academic career abroad & 17.9 & 33 \\
I need to get a foreign degree to be promoted in my current company in the home country & 4.9 & 9 \\
To come back to the home country and start a business & 2,7 & 5 \\
To pursue an academic career in the home country & 2.7 & 5 \\
To come back and look for a job in the home country & 2.7 & 5 \\
\hline I will stay abroad for personal reasons & 1.6 & 3 \\
\hline I already have a job offer in the home country & 1.1 & 2 \\
\hline
\end{tabular}

Table 3

Pull Factors that are Most Likely to Encourage Students to Stay in the Host Country after Graduation

\begin{tabular}{|l|c|c|}
\hline \multicolumn{1}{|c|}{ Factor } & \% of answers & N \\
\hline Higher quality of life in the host country & 18.2 & 112 \\
High salary rate in the host country & 15.8 & 97 \\
Better career opportunities in the host country & 13.5 & 83 \\
More dynamic economic development in the host country & 9.3 & 57 \\
Lower economic risks in the host country & 9.3 & 57 \\
Higher demand for my profession in the host country & 9.3 & 57 \\
More jobs available in the host country & 9.1 & 56 \\
Low level of corruption in the host country & 8.0 & 49 \\
Personal circumstances & 6.0 & 37 \\
My family member already live in the host country and will provide support & 1.6 & 10 \\
\hline
\end{tabular}


Pull Factors that are Most Likely to Attract Students Back to Russia After Graduation from a Foreign Institution

\begin{tabular}{|l|c|c|}
\hline \multicolumn{1}{|c|}{ Factor } & \% of answers & N \\
\hline Personal circumstances (family, partner in the home country) & 67.9 & 125 \\
I want to contribute to the development of my home country & 38.5 & 71 \\
Financial issues do not allow me to stay in the host country & 28.8 & 53 \\
I feel more comfortable at home & 26.0 & 48 \\
I have a job offer in my home country & 17.9 & 33 \\
With international diploma I will be more competitive in my home country & 17.3 & 32 \\
I will have to go back in accordance with conditions of my scholarship & 14.1 & 26 \\
My profession is more in demand/better paid at my home country & 9.2 & 17 \\
\hline
\end{tabular}

As Fig. 2 shows, the share of the students who plan to return right after graduation is comparatively low. For those who have not made their decision about returning versus staying broad, initiatives of a different nature can be considered. For example, the government can offer partial or full compensation of tuition expenses for those who return home, or offer other economic motivations, such as better conditions for the housing loans. Another set of measures can be connected with providing job opportunities and ensuring employment for these students while they are still studying abroad, which would prevent them from seeking employment in the recipient country.

There is a significant group of students who have a clear intention to stay abroad (42.4\%). Though they may seem to be entirely lost for the Russian job market, it is still possible to involve them in an indirect way and consider brain circulation as a solution. To keep these students connected to the Russian job market, one option can be launching an Internet portal that would connect Russian employers and students who stay abroad. Students can be hired on short-term or distant, «outsource» bases, and in this way provide their expertise to Russian businesses, industry and governmental sector.

The research reveals several trends that can be applied for improvement and development of the existing policies at the national level. The study indicates that almost $50 \%$ of students have not heard about Global Education program, and therefore do not consider applying. Active promotion of the federal scholarship program, better communication with those who consider it as a way of funding their studies, and widening the list of employers can have a significant positive effect on the development of intellectual potential in Russia.

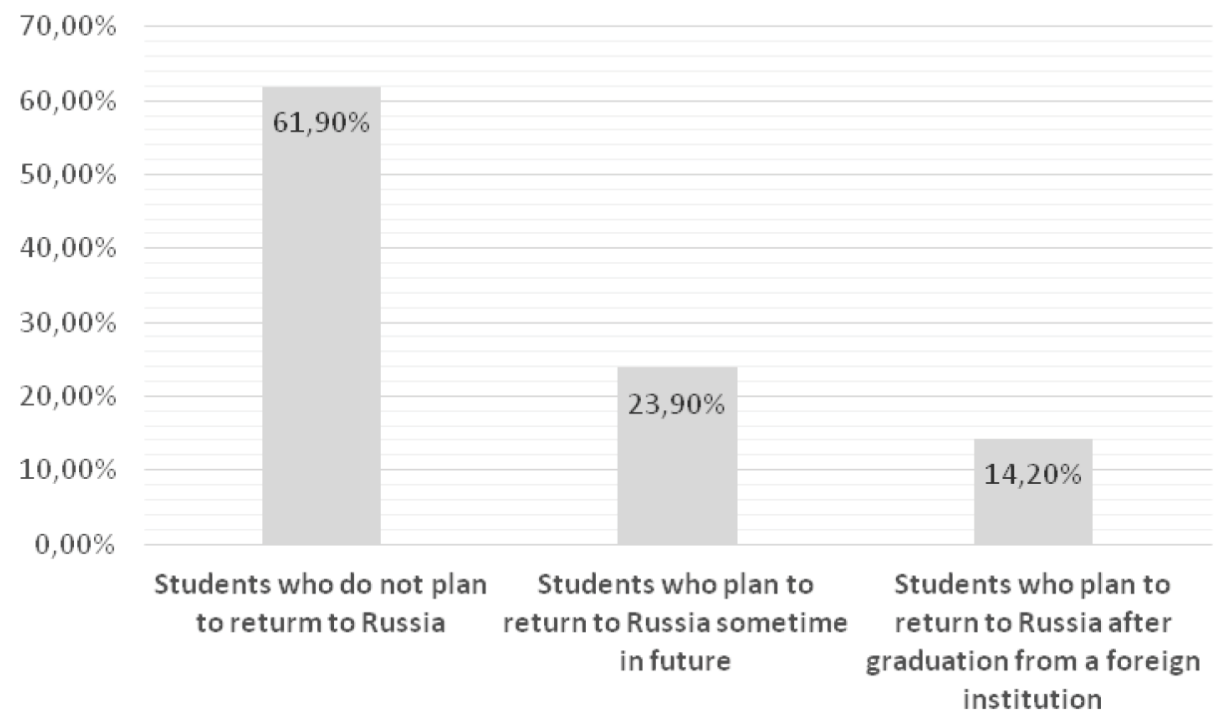

Fig. 2. Distribution of the respondents by groups according to their plans towards emigration after graduation from a foreign institution 
The second direction of initiatives can be related to the development of a clear message for those who still have not decided on their immigration or return plans, in order to demonstrate that these graduates are welcome and their expertise is required back home. This can be done through social media, through career fairs for these students, or through providing beneficial economic conditions. The share of the students who consider contribution to their country as one of the major reasons to return to Russia is quite significant (38.5\%).

On the institutional level, a wider range of double-degree programs may be one of the ways to address brain drain. The share of the students who would prefer double-degree programs to the full degree abroad is significant (45.8\%), and these students could be required to return home for graduation. In addition, institutions may consider cooperation with industry and businesses to provide partial funding for those who want to participate in these programs and offer further employment for these students. This approach may extend the number of participants, address the issues of economic inequality, and provide employment for students after graduation. In addition, these measures can help to involve more students in outbound student mobility, as well as to secure their return.

While the existing policies on retention and return require improvement, the engagement policies are currently not implemented in Russia at all. This reveals a significant gap in Russian policies, as the majority of prospective students consider emigration after graduation as the most possible option. The most popular reason for emigration for these students is related to economic considerations, which cannot be changed in the short-term. However, the experience of other countries shows that it is possible to stimulate brain circulation and engage these students in the Russian economy [15]. The summary of the initiatives which can be implemented on the national and institutional levels is shown in Table 5.

The existing initiatives undoubtedly contributing to the development of Russian students' potential, there is an imbalance in managing the outbound student mobility in Russia, which causes two major concerns. First, the percentage of internationally mobile students remains comparatively low. There is a demand for well-elaborated initiatives that can create a critical mass of individuals who obtain high-quality international expertise and can use these skills to contribute to the development of Russian economy and society. Second, the significant part of mobile Russian students remains overlooked. There is no strategy to connect with those who fund their studies through scholarships received from recipient countries and institutions or those who self-fund their studies. In addition, there is no understanding or clear policies for sustaining the dialogue with these students and preventing brain drain.

In order to prevent brain drain, some initiatives can be implemented on the regional level as well,

Table 5

Possible policies and initiatives for decreasing the risk of the student brain drain from Russia

\begin{tabular}{|c|c|c|c|}
\hline Type of policy & Level & Improvement of existing policies & New initiatives \\
\hline Retention & National & Improvement of quality of higher education & Subject for further research \\
\hline Retention & Institutional & $\begin{array}{l}\text { 1. Developing more programs taught in English. } \\
\text { 2. Developing programs that meet the } \\
\text { requirements of the modern economy. } \\
\text { 3. Meaningful internationalization at home }\end{array}$ & Subject for further research \\
\hline Return & National & $\begin{array}{l}\text { Scholarship program «Global Education»: } \\
\text { 1) increase of funding for the program; } \\
\text { 2) marketing and communication, making } \\
\text { program «visible» for prospective students }\end{array}$ & $\begin{array}{l}\text { 1. Partial or full compensation of student's } \\
\text { tuition expenses upon return. } \\
\text { 2. Providing job opportunities and ensuring } \\
\text { working places. } \\
\text { 3. Providing beneficial financial offers for } \\
\text { Russian students with the international degree }\end{array}$ \\
\hline Return & Institutional & $\begin{array}{l}\text { Increase of number of dual-degree programs in } \\
\text { cooperation with foreign institutions }\end{array}$ & $\begin{array}{l}\text { Beneficial conditions for academics with foreign } \\
\text { qualifications }\end{array}$ \\
\hline Engagement & National & - & $\begin{array}{l}\text { 1. Development of Russian diaspora abroad. } \\
\text { 2. Development of networks between Russian } \\
\text { students and graduates abroad and Russian } \\
\text { economy }\end{array}$ \\
\hline Engagement & Institutional & - & $\begin{array}{l}\text { Enhanced cooperation with Russian graduates } \\
\text { abroad }\end{array}$ \\
\hline
\end{tabular}


especially within large countries like Russia. For example, creation of regional centers for innovation and research can be considered one of initiatives like that. However, in this research, the regional level has not been considered for two reasons. First, most of the initiatives come from the national government, even if they are implemented on the regional level. Second, the regions have many specific features and different financial, educational and industrial capacity, and analysis of these policies requires a detailed analysis of each region.

At the same time, institutions can be very influential actors. First, they can serve as anchors for those students who wish to return to Russian academia if they provide opportunities for professional growth and financial benefits (following the example of China). More importantly, institutions can also serve initiators of brain circulation. While it may be a challenge to provide the same life conditions and the same level of salary for Russian graduates of foreign institutions, involving them in teaching and research activities and keeping in touch with them through networking, joint projects and research collaborations looks a more realistic and doable task.

However, the lack of comprehensive measures, compared to other countries, for example, China or Brazil, evidently indicates that at the national level the Issue of brain drain is not recognized, and the community of Russian students and graduates abroad is currently in the blind spot from the national perspective.

For future research and elaboration of more specific recommendations, it might be useful to analyze the tracks and motivations of the Russian students of foreign institutions after their graduation, which should help to develop a comprehensive understanding of possible mechanisms to support brain circulation. In addition, the analysis of particular Russian institutions, private companies and research centers that manage to attract Russian graduates back to the country after graduation can be helpful for developing the national initiatives in the Russian context.

\section{References}

1. Altbach P. The International Imperative in Higher Education. Rotterdam ; Boston ; Taipei : Sense Publishers, 2013, 198 p. (In Eng.).

2. Knight J. International Education Hubs: Student, Talent, Knowledge-Innovation Models. Dordrecht : Springer, 2014. 251 p. (In Eng.).

3. Teichler U. Internationalization Trends in Higher Education and the Changing Role of International Student Mobility. Journal of International Mobility, 2016, vol. 1, no. 5, pp. 177-216. (In Eng.)

4. Zajda J. Globalisation and Education Reforms: Paradigms and Ideologies. Globalisation and Education
Reforms. Globalisation, Comparative Education and Policy Research. Dordrecht : Springer, 2018. 247 p. (In Eng.).

5. Ushakov I. G., Malaha I. A. Utechka umov: masshtaby, prichiny, posledstviya [Brain Drain: Magnitude, Reasons, Results]. Moscow : Librokom, 2011. 178 p. (In Russ.).

6. Knight J. Updating the Definition of Internationalization. International Higher Education, 2003, no. 33, pp. 2-3. (In Eng.).

7. Knight J. Education Hubs: A Fad, a Brand, an Innovation? Journal of Studies in International Education, 2011, vol. 15, no. 3, pp. 221-240. (In Eng.).

8. UNESCO. Global Flow of Tertiary-Level Students (2014), available at: from http://uis.unesco.org/en/ uis-student-flow (accessed 14.10.2019). (In Eng.).

9. Li H. The Role of the Migration Industry in Chinese Student Migration to Finland: Towards a New Mesolevel Approach. In: Du X., Liu H., Dervin F. (eds). NordicChinese Intersections on Education. New York, 2017, pp. 21-49 (In Eng.).

10. Marginson S.. The Global Higher Education Market and its Tensions. Papers for Discussion at the AERA Division, J/NAFSA Meeting (2013, April), available at: https://www. nafsa.org/_File/_/global_higher_ed_market.pdf (accessed 10.11.2019). (In Eng.).

11. Altbach P. Globalization and the University: Realities in an Unequal World. Tertiary Education and Management, 2004, vol. 10, pp. 32-33. (In Eng.).

12. Li M., Bray M. Cross-Border Flows of Student for Higher Education: Push-Pull Factors and Motivations of Mainland Chinese Students in Hong Kong and Macau. Higher Education, 2007, no. 53, pp. 791-818. (In Eng.).

13. Mitchell N. Can Lithuania turn brain drain into brain gain? BBC News (2015, 18 February), available at: https://www.bbc.com/news/business-31488046 (accessed 12.10.2019). (In Eng.).

14. Saint-Blancat C. Italy: Brain Drain or Brain Circulation? International Higher Education, 2019, no. 96, pp. 1-11. (In Eng.).

15. Gribble G. Policy Options for Managing International Student Migration: the Sending Country's Perspective. Journal of Higher Education Policy and Management, 2009, vol. 30, no. 1, pp. 25-39. (In Eng.).

16. Moreira I. Brazilian Science at Crossroads. Science, 2003, vol. 301, pp. 1-196. (In Eng.).

17. Saravia N., Miranda J. Plumbing the Brain Drain. Bulletin of the World Health Organization, 2004, vol. 82, no. 8, pp. 608-615. (In Eng.).

18. Zweg D. Competing for Talent: China's Strategies to Reverse the Brain Drain. International Labor Review, 2006, vol. 134, no. 1/2, pp. 65-89. (In Eng.).

19. Meyer J., Brown M. Scientific Diasporas: A New Approach to the Brain Drain. Management of Social Transformation-MOST, 2019, Discussion Paper No. 41, available at: http://www.unesco.org/most/meyer.htm (accessed 12.10.2019). (In Eng.).

20. Meyer J. Network Approach versus Brain Drain: Lessons from the Diaspora. International Migration, 2001, vol. 39, no. 5, pp. 91-110. (In Eng.).

21. Saxenian A. From Brain Drain to Brain Circulation: Transnational Communities and Regional Upgrading in 
India and China. Studies in Comparative International Development, 2005, vol. 40, no. 2, pp. 35-61. (In Eng.).

22. Pravitel'stvo Rossiiskoi Federatsii. Bulleten' obrazovaniya. Reforma vysshego obrazovaniya: domashnii i mezhdunarodnii opyt [Government of Russian Federation. Bulletin on education. Reform of higher education: domestic and international experience] (2017), available at: http://ac.gov.ru/ files/publication/a/13584.pdf (accessed 14.10.2019). (In Russ.).

23. NUFFIC Report. International Student Recruitment: Policies and Developments in Selected Countries, available at: https:/www.nuffic.nl/en/publications/find-a-publication/international-student-recruitment.pdf (accessed 01.07.2019). (In Eng.).

24. Karlsen E. Leaving Russia? Russian Students in Norway. Higher Education Dynamics, 2017, vol. 48, pp. 263-276. (In Eng.).

25. Chankseliani M., Hessel G. International Student Mobility from Russia, Eastern Europe, Caucasus, and Central Asia to the UK: Trends, Institutional Rationales and Strategies for Student Recruitment (Research report). Oxford, UK : The Centre for Comparative and International Education, University of Oxford (2016), available at: https:/ora.ox.ac.uk/objects/uuid\%3Afdbb4023-16fe-45429b2b-1b47993acf68 (accessed 28.09.2019). (In Eng.).

26. Globalnoe Obrazovanie [Global Education] (2017). Statistics Report, available at: http://educationglobal.ru/ fileadmin/downloads/GO_1712_new_final.pdf (accessed 18.10.2019). (In Russ.).

27. Vashurina E. V., Vershinina O. A., Evdokimova Y. Sh. Sistema razvitiya sovmestnykh obrazovatel'nykh programm v rossiiskikh vuzakh cherez prizmu strategii internatsionalizatsii [Emerging System of Joint Degree Programs in Russian Universities in the Context of Internationalization Strategy]. Universitetskoe upravlenie: praktika i analiz, 2014, no. 2 (90), pp. 41-49. (In Russ.).

28. Altbach P. G. Comparative Higher Education: Knowledge, the University, and Development. Hong Kong: Greenwood Publishing Group, 1998. 248 p. (In Eng.).

29. Todaro M. International Migration in Developing Countries. Geneva: International Labor Organization, 1976. 106 p. (In Eng.).

Submitted on 17.03.2020
30. Douglas S. M., Arango J., Hugo G., Kouaouci A., Pellegrino A., Taylor E. Theories of International Migration: A Review and Appraisal. Population and Development Review, vol. 19, no. 3, pp. 431-466. (In Eng.).

31. Todaro M. P., Maruszko L. Illegal Migration and US Immigration Reform: A Conceptual Framework. Population and Development Review, 1987, vol. 13, no. 1, pp. 101-114. (In Eng.).

32. Robertson S., Weis L., Rizvi, F. The Global Auction: the Broken Promises of Education, Jobs and Incomes. British Journal of Sociology of Education, 2011, vol. 2, no. 32, pp. 293-311. (In Eng.).

33. Stark O., Levhari D. On migration and risk in LDC. Economic Development and Cultural Change, 1982, vol. 31, pp. 191-196. (In Eng.).

34. Stark O. The Migration of Labor. Cambridge : Basil Blackwell, 1991. 406 p. (In Eng.).

35. Taylor J. Different Migration, Networks, Information and Risk. In: Stark O. (ed.) Research in Human Capital and Development, vol. 4, Migration, Human Capital, and Development, Greenwich, 1986, pp. 147-171. (In Eng.).

36. Piore M. Birds of Passage: Migration Labor in Industrial Societies. Cambridge : Cambridge University Press, 1979. 240 p. (In Eng.).

37. Faist T. The Volume and Dynamics of International Migration and Transnational Social Spaces. Oxford : Clarendon Press, 2000. 380 p. (In Eng.).

38. Haigh M. From Internationalization to Education for Global Citizenship: a Multi-Layered History. Higher Education Quarterly, 2014, vol. 68, no. 1, pp. 6-27. (In Eng.).

39. Sen A. Commodities and Capabilities. Amsterdam: North Holland, 1985. 130 p. (In Eng.).

40. Juran S. International Migration Seen through the Lens of Amartya Sen's Capability Approach. Migration Policy Practice, 2016, vol. 6, pp. 24-27. (In Eng.).

41. Srinivasan R., Lohith C.P. Pilot Study-Assessment of Validity and Reliability. In: Strategic Marketing and Innovation for Indian MSMEs. India Studies in Business and Economics, Springer, 2017, pp. 43-49. (In Eng.).

Accepted on 26.05.2020

\section{Information about the author}

Ekaterina A. Minaeva - analyst, Laboratory for University Development, National Research University «Higher School of Economics»; eminaeva@hse.ru. 